Nemanja Lojanica

Ekonomski fakultet Univerzitet u Kragujevcu nlojanica@kg.ac.rs

Prevod

obezbedio

autor
MAKROEKONOMSKI

EFEKTI MONETARNE TRANSMISIJE U

SRBIJI: SVAR PRISTUP

\title{
Rezime
}

Ocenjivanje delovanja transmisionog mehanizma monetarne politike predstavlja jedno od esencijalnih makroekonomskih pitanja. Osnovni cilj ovog rada je da se odgovarajućom teorijskometodološkom i empirijskom analizom preispitaju efekti monetarne politike na ukupnu ekonomsku aktivnost i cene u privredi Republike Srbije. Makroekonometrijsko modeliranje je realizovano primenom nerekurzivnog SVAR modela, a kao pogodan vremenski okvir odabran je period 2007 M012015 M12. Sprovedenim istraživanjem je ustanovljeno da od monetarnih šokova veoma značajan uticaj na kretanje i fluktuacije u outputu ima novčana masa, kao i da devizni kurs predstavlja najznačajniji kanal monetarne transmisije u Srbiji. Nosioci ekonomske politike treba da imaju u vidu ograničeno dejstvo deviznog kursa u dugom roku. Takođe, monetarne vlasti posebnu pažnju treba da obrate na kanal kamatne stope, kao osnovni instrument monetarne politike, koji ima mali uticaj zbog visokog stepena evroizovanosti nacionalne ekonomije.

Ključne reči: monetarna politika, kanali transmisije, Republika Srbija, SVAR

JEL: E32, E52 


\section{MACROECONOMIC EFFECTS OF MONETARY TRANSMISSION IN SERBIA: SVAR APPROACH}

Nemanja Lojanica

Faculty of Economics, University of Kragujevac nlojanica@kg.ac.rs
Translation provided by the author

\section{Summary}

Evaluations of the effects of transmission mechanisms in monetary policy are one of the essential macroeconomic issues. The main objective of this article is to examine the effects monetary policy has on the overall economic activity and prices in the Republic of Serbia by using the appropriate theoretical, methodological and empirical frame. Macroeconometric modelling has been carried out by means of the non-recursive SVAR model. The time period ranging from M01 2007 - M12 2015 has been selected as a suitable timeframe. The study has shown that the exchange rate is the most important channel of monetary transmission in Serbia. Also, the study has revealed that the movements and fluctuations in output are highly influenced by money supply. Policy makers should bear in mind the limited impact of exchange rates in the long run. Also, monetary authorities should pay special attention to the interest rate channel, as the main instrument of monetary policy, which has little influence due to the high rate of euroisation of the national economy.

Keywords: monetary policy, transmission channels, Republic of Serbia, SVAR

JEL: E32, E52 


\section{Uvod}

Utvrđivanje najznačajnijih kanala putem kojih se dejstvo monetarne politike prenosi na realnu ekonomiju, predstavlja jedno od centralnih makroekonomskih pitanja. Uloga monetarnih vlasti jeste da na adekvatan način procene transmisioni mehanizam, kako bi svoje akcije usmerile na ključne makroekonomske varijable. Monetarna politika, zapravo predstavlja procese putem kojih monetarne vlasti kontrolišu ponudu novca sa ciljem da ostvare održivi ekonomski rast i stabilnost cena. Iako monetarne vlasti imaju jasno izražene ciljeve u pogledu monetarne politike, prisutne su brojne teškoće u procesu prenošenja efekata na realni sektor, jer su znanja o transmisionom mehanizmu i dalje ograničena.

$\mathrm{U}$ fokusu ovog rada se nalazi ispitivanje efikasnosti transmisionog mehanizma monetarne politike u Srbiji. Osnovni motiv za ovu analizu leži u činjenici da specifičnost nacionalne ekonomije, koju karakteriše visoka evroizovanost, kao i to što Srbija predstavlja malu i otvorenu ekonomiju, nameće potrebu za (pre)ispitivanje važnosti pojedinih kanala transmisije. Cilj ovog rada je da teorijskom analizom pruži koristan okvir nosiocima ekonomske politike pregledom odabranih kanala transmisije, kao i da ukaže na potencijalne efekte ovih kanala na realne varijable u zemljama u razvoju. Pored toga, ciljje i da se empirijskom analizom preispitaju efekti monetarne politike na ukupnu ekonomsku aktivnost i cene, a u posebnom fokusu će se naći kanali transmisije, devizni kurs i (referentna) kamatna stopa (osnovni instrument monetarne politike). Na osnovu prethodno istaknutih ciljeva, nameću se sledeća istraživačka pitanja:

i. Da li monetarni šokovi utiču na fluktuacije outputa i cena u maloj otvorenoj ekonomiji;

ii. Da li je devizni kurs i dalje najznačajniji transmisioni kanal u visoko evroizovanoj privredi;

iii. Kakva je uloga referentne kamatne stope kao osnovnog instrumenta monetarne politike u predviđanju kretanja realnih pokazatelja, pre svega u kretanju inflacije (price puzzle);

iv. Da li eksterni šokovi imaju značajniji uticaj na realna kretanja u Srbiji od domaćih monetarnih šokova?
Budući da se radi o temi koja se u velikoj meri ispituje, kako na globalnom nivou, tako i u Srbiji, doprinos rada se sastoji u primeni metodologije (SVAR model) koja, prema saznanju autora, nije korišćena za ispitavanje efikasnosti transmisionog mehanizma $\mathrm{u}$ Srbiji, a poseduje značajne prednosti, u smislu prikazivanja efekata strukturnih šokova na varijable od interesa. Takođe, vremenski horizont posmatranja varijabli obuhvata i efekat globalne krize, te su i efekti ovog dešavanja uključeni u model kao egzogeni faktor. I na kraju, u rad je uključeno i dejstvo eksternih faktora, i ispitivan efekat šokova izvan nacionalne ekonomije na realna kretanja u Srbiji. Rad se nakon uvoda sastoji iz sledećih delova: Pregled literature u kojem su pojašnjeni odgovarajući kanali transmisije i njihovi realni efekti, Podaci i metodologija, gde su definisane varijable i odgovarajuća metodologija istraživanja, Empirijski rezultati, gde su prikazani najznačajniji rezultati, i Zaključak, gde su sumirani rezultati i diskutovani sa aspekta makroekonomskih implikacija.

\section{Pregled literature}

Transmisioni mehanizam monetarne politike zavisi od velikog broja faktora koji su specifični za nacionalnu ekonomiju. Različite strukture privrede mogu voditi različitoj važnosti pojedinih kanala transmisije. U malim otvorenim ekonomijama koje su opredeljene za fiksni devizni kurs, kretanja kapitala nisu ograničena, i domaća i inostrana dobra su savršeni supstituti. U tom slučaju, ponuda novca se nalazi van kontrole monetarnih vlasti. U takvoj situaciji, monetarna politika nema realne efekte. Sa druge strane, u maloj otvorenoj ekonomiji sa fleksibilnim deviznim kursom, kanal deviznog kursa igra važnu ulogu $\mathrm{u}$ transmisiji šokova u ekonomiji. Takav slučaj je sa privredom Republike Srbije, koja je pritom i visoko evroizovana ekonomija. Dragutinović (2008) je analizirala efekte različitih kanala transmisije monetarne politike $\mathrm{i}$ njihove implikacije na okvir i instrumente monetarne politike u Srbiji. Utvrđeno da u privredi Srbije deluju dva kanala, kanal deviznog kursa i kanal očekivanja. Takođe, Bungin i saradnici (2015) su ispitivali efekte transmisionog mehanizma u 


\section{Introduction}

One of the central macroeconomic issues is to identify the channels through which the macroeconomic policy impacts are transferred to the real economy. The role of monetary authorities is to adequately estimate the transmission mechanisms so that their actions would be focused on the key macroeconomic variables. Monetary policy represents all those processes which are used by the monetary authorities in controlling the money supply and whose aim is to provide sustainable economic growth and price stability. Even though the monetary authorities have the clear goals in terms of monetary policy, numerous difficulties occur when the effects are being transferred on the real sector because our understanding of transmission mechanisms is still limited.

This paper's focus is to examine the efficiency of the monetary policy transmission mechanism in Serbia. The leading motivation for this analysis is that the national economy is specific (small and open economy characterized by high level of euroisation) and thus requires a (re)examination of the importance of certain transmission channels. The aim of this paper is to provide a useful framework for economic policymakers through theoretical analysis which would review the selected transmission channels and indicate their potential effects on the real variables in the developing countries. In addition, the aim of this paper is to reexamine the effects of monetary policy on total economic activity and prices with a special emphasis on transmission channels, exchange rate and (reference) interest rate (the basic instrument of monetary policy) by means of the appropriate empirical analysis. Based on the previously defined goals, the following research questions arise:

i. Do monetary shocks have an influence on output and price fluctuations in a small open economy;

ii. Is the exchange rate still the most important transmission channel in a highly euroized economy;

iii. What is the role of the reference interest rate, as the basic instrument of macroeconomic policy, in predicting the movements of real indicators, primarily inflation (price puzzle); iv. Do external shocks have a more significant impact on the real movements in Serbia than domestic monetary shocks?

The topic has been examined both worldwide and in Serbia, but the contribution of this paper is in the methodology used in this paper. SVAR model has been used, which, based on the current knowledge of the author, has not been used in examining the efficiency of the transmission mechanisms in Serbia. This model has significant advantages in terms of enabling the identification of effects of structural shocks on selected variables. Also, a time horizon of the observation includes the effects of the global crisis which are, thus, included in the model as an exogenous factor. In other words, the paper includes the external factors and examines the impact of the shocks external to the national economy. The paper consists of the following chapters: Literature Review, elaborating on transmission channels and their real effects, Data and Methodology, defining the variables and methodology, Empirical Results, presenting the most significant results, and Conclusions, summarizing the results from the perspective of macroeconomic implications.

\section{Literature Review}

Transmission mechanisms of monetary policy depend on numerous factors which are specific for every national economy. The different structures of an economy can result in the different degrees of importance of certain transmission channels. In small open economies which have opted for the fixed exchange rate, the capital movement is not limited, while domestic and foreign goods are the perfect substitutes. In that case, money supply is not under the control of monetary authorities. In such circumstances, monetary policy has no real effects. On the other hand, in a small open economy with flexible exchange rates, the channel of exchange rate plays an important role in the transmission of shocks. Dragutinović (2008) has analysed the effects of different channels in the transmission of monetary policy and their implications on the framework and instruments of monetary policy in Serbia. It has been estimated that in the Serbian economy there are two channels, the exchange rate channel and the expectations channel. Bungin, 
Srbiji, i ustanovili su da devizni kurs ima daleko jači uticaj na privredna kretanja nego referentna kamatna stopa, iako ima naznaka o postojanju kamatnog kanala.

Ocena transmisionog mehanizma $u$ jednoj zemlji se ne može generalizovati na sve nacionalne ekonomije. Takođe, značaj pojedinih kanala transmisije se umnogome razlikuje među nacionalnim ekonomijama. Faktori kao što su ekonomski i finansijski razvoj, umnogome utiču na značaj pojedinih kanala transmisije. Aranžmani deviznog kursa, institucionalne i političke postavke, značajno se razlikuju među ekonomijama i imaju uticaj na efekte kanala transmisije.

\section{Kanal kamatne stope}

Prema mišljenju većine ekonomista, kanal kamatne stope predstavlja jedan od najznačajnijih kanala monetarne transmisije. Svojevremeno su Gerlach i Smets (1995) istakli da u makroekonometrijskim modelima koje sprovode centralne banke, transmisioni mehanizam je modeliran uz pretpostavku da je kamatna stopa najznačajniji kanal. Centralna banka određuje kratkoročnu kamatnu stopu, koja utiče na ostale kamatne stope, nezavisno od njihove ročnosti, na druge cene aktive i na devizni kurs. Ove promene $u$ finansijskim varijablama nakon toga utiču na ukupni output i cene, kroz različite komponente trošenja. Uloga novca je u većini slučajeva pasivna, jer je on određen nivoom tražnje. Bazirajući se na kejnzijanskom pristupu, Mishkin (2001) je tradicionalni kanal kamatne stope predstavio na sledeći način:

$$
M \uparrow \mapsto P^{e} \uparrow \mapsto \pi^{e} \uparrow \mapsto r \quad I \mapsto I \uparrow \mapsto Y \uparrow
$$

Ekspanzijom novčane mase (Mi) može se povećati očekivani nivo cena $\left(P^{e} \uparrow\right)$, koji povećava očekivanu stopu inflacije $\left(\pi^{e} \uparrow\right)$, a time se smanjuje realna kamatna stopa $\left(r I=i-\pi^{e}\right)$, i stimulišu investicije, i u krajnjoj instanci ukupni output. Kanal kamatne stope predstavlja osnovni mehanizam u makroekonomskim modelima koji se tiču transmisionog mehanizma. Osnovna ideja je ta, da se povećanje nominalne kamatne stope translira u povećanje realne kamatne stope i troška kapitala, za dati stepen rezistentnosti cena. Ove promene dovode do odlaganja potrošnje ili smanjenja investicione potrošnje. Ovaj mehanizam je oličen u kejnzijanskoj IS krivi, ili novokejnzijanskoj forward-looking jednačini. Taylor (1995) je proširio teoriju, naglašavajući da monetarna kontrakcija podrazumeva rast nominalnih kamatnih stopa, a to vodi rastu realnih kamatnih stopa i smanjenju fiksnih poslovnih investicija, stambenih investicija, trajnih izdataka potrošača i inventarnih investicija, što u konačnom smanjuje agregatnu tražnju i output.

Performanse kanala kamatne stope mogu da oslabe $\mathrm{u}$ zemljama $\mathrm{u}$ razvoju, gde su finansijska tržišta plitka i gde se država nalazi u većinskom vlasništvu inostranih banaka. U takvim zemljama, ograničenja na kamatne stope imaju obavezujući karakter, a državne banke imaju ograničenja da pozajmljuju sredstva na osnovu komercijalnih kriterijuma (Horvath i Maino, 2006). Claus (2011) je u svojoj empirijskoj studiji pokazao da je kanal kamatne stope značajniji od drugih kanala (kreditnog i kanala deviznog kursa), jer je uticaj ovog kanala transmisije na troškove potrošnje, stopu prinosa kapitala i deviznog kursa visoko signifikantan. Sa druge strane, $\mathrm{u}$ literaturi su prisutne i studije (Bernanke i Gertler, 1995, Charoenseang i Manakit 2007, Poon i Wong, 2011) koje ukazuju na neadekvatnost ovog kanala transmisije.

\section{Kanal deviznog kursa}

Veliki broj studija je u prošlosti ispitivao zavisnost nacionalnog nivoa cena i režima deviznog kursa. Na primer, Broda (2006) je istakao da je u zemljama u razvoju koje sprovode politiku fiksnog deviznog kursa, prisutan viši nivo cena nego $u$ onima sa fleksibilnim deviznim kursom. On je dalje istakao da tendencija sprovođenja ekspanzivne monetarne politike može voditi realnoj apresijaciji kursa u zemljama sa režimom fiksnog deviznog kursa, ali ne $u$ onima sa fleksibilnim kursem. Ovakva tendencija je naročito izražena $u$ zemljama $u$ razvoju, kao i u onim zemljama koje postavljaju devizni kurs da bi stabilizovale inflaciju. Ndung'u (1999) je istakao da su devizni kurs i monetarna politika ključni instrumenti ekonomskog menadžmenta 
et al. (2015) have also investigated the effects of transmission mechanisms in Serbia and they have found that the exchange rate has a significantly stronger impact on economic trends than the reference interest rate, even though there are certain indications about the existence of the interest channel.

The evaluation of transmission mechanisms in one country cannot be generalized for all national economies since the influence of separate transmission channels widely differs among the national economies. The factors such as economic and financial development have a strong impact on separate transmission channels. The exchange rate arrangements, institutional and political settings, differ significantly among economies and they also have an influence on the effects of transmission channels.

\section{Interest Rate Channel}

In the opinion of most economists, the interest rate channel is one of the most important channels of monetary transmission. Gerlach and Smets (1995) have emphasized that in macroeconometric models implemented by central banks transmission mechanisms are modeled following the hypothesis that the interest rate is the most significant channel. Central banks estimate a short-term interest rate which has an impact on the remaining interest rates, irregardless of their maturity, on other asset prices and on exchange rates. Further on, these changes in financial variables have an impact on the total output and prices through the different components of spending. The role of money in most cases is passive because it is determined by the demand level. Based on the Keynesian approach, Mishkin (2001) has presented the traditional interest rate channel in the following manner:

$$
M \uparrow \mapsto P^{e} \uparrow \mapsto \pi^{e} \uparrow \mapsto r \quad I \mapsto I \uparrow \mapsto \Upsilon \uparrow
$$

With the expansion of the money supply (MI), the expected price level $\left(P^{e \uparrow} \uparrow\right.$ can increase, which in turn increases the expected inflation level $\left(\pi^{e} \uparrow\right)$, thereby reducing the real interest rate $\left(r I=i-\pi^{e}\right)$ and stimulating investments and ultimately increasing the total output. The interest rate channel is the basic mechanism in macroeconomic models concerning transmission mechanisms. The basic idea is that an increase in the nominal interest rate translates into an increase in the real interest rate for the given level of price resistance. These changes result in a spending delay or a reduction in investment spending. This mechanism is embodied in the Keynesian IS curve or the new-Keynesian forward-looking equation. Taylor (1995) has expanded the theory emphasizing that monetary construction implies the growth of nominal interest rate, and that it leads to growth in real interest rates and reduction of fixed business investments, permanent consumer expenditure and inventory investments. Finally, it reduces the aggregate demand and output.

The performance of the interest rate channel in developing countries, where financial markets are shallow and the country is majority-owned by foreign banks, can weaken. In such countries, the limitations in interest rates have a binding character, and state banks have restrictions on borrowing funds based on the commercial criteria (Horvath \& Maino, 2006). Claus (2011) has shown that the interest rate channel is more significant than other channels because the influence of this channel on consumption spending, rate of return on capital and exchange rate is highly significant. On the other hand, there are studies (Bernanke \& Gertler, 1995; Charoenseang \& Manakit 2007; Poon \& Wong, 2011) which suggest the inadequacy of this transmission channel.

\section{Exchange Rate Channel}

Numerous past studies have examined the dependency of the national price level and the exchange rate regime. For example, Broda (2006) has emphasized that developing countries with the fixed exchange rate policy have a higher level of prices than the countries with flexible exchange rates. He has also pointed out that the tendency of running expansive monetary policy can lead to the real exchange rate appreciation in the countries with the fixed exchange rate regime, but not in those with the flexible exchange rate. This tendency is particularly pronounced in developing countries. Ndung'u 
i procesa stabilizacije u zemljama u razvoju, gde su niska stopa inflacije i međunarodna konkurentnost ključni targeti ekonomske politike. On je dalje istakao da monetarni šokovi utiču na fluktuacije deviznog kursa, ali i da važi obratno. Ovim se sugeriše da postoji snažna povezanost između politike transmisionog mehanizma, režima deviznog kursa i efektivnosti monetarne politike. Drugim rečima, odabrani režim politike deviznog kursa u nacionalnoj ekonomiji determiniše koji su kanali transmisionog mehanizma monetarne politike efikasniji i efektivniji. Ovo, naravno, zavisi i od ostalih faktora u ekonomiji. Kanal deviznog kursa se prema Obstfeldu i Rogofu, (1995) transmituje efekte monetarne politike na sledeći način:

$$
\begin{gathered}
M I \mapsto R \uparrow \mapsto \text { realni devizni kurs }(E) \uparrow \mapsto \text { neto } \\
\text { izvoz }(N X) I \mapsto Y \downarrow \quad(2)
\end{gathered}
$$

Povećanje vrednosti domaće valute se označava sa E1. Ovaj model ilustruje da monetarna politika vodi povećanju realnog deviznog kursa, a efekti se transmituju na neto izvoz i ukupni output. Na strani ponude, realna apresijacija domaće valute smanjuje domaće cene uvezenih dobara, što direktno smanjuje domaću stopu inflacije, putem deviznog kanala exchange rate pass-through (McCallum i Nelson, 2001). Nivo pass-through ka nivou lokalnih cena uvezenih dobara, i ukupne inflacije zavisi od udela uvoza, magnitude apresijacije i njenog tajminga, kao i makroekonomskih karakteristika nacionalne ekonomije (Kara i Ogunc, 2005). Na primer, Devereux et. al., (2003) ističu da nacionalne ekonomije sa niskom volatilnošću novčane mase imaju niske stope exchange rate passthrough kanala i obratno. Vilaret i Palić (2006) su ocenjivali pass-through efekat deviznog kursa na inflaciju u Srbiji. Rezultati ADL i VAR metodologije pokazali su da je efekat deviznog kursa na inflaciju u Srbiji relativno visok, ali i da je kao u slučaju većine zemalja nepotpun i manji od jedinice.

Iako se u mnogim studijama za industrijalizovane zemlje pokazalo da ovaj transmisioni mehanizam nije dovoljno efikasan (McCarthy 1999, Burstein i saradnici, 2002, Campa i Goldberg. 2002), on je i dalje jako značajan za male otvorene ekonomije (Afandi, 2005, Aslanidi, 2007). Cushman i Zha (1997) su na primeru monetarne politike Kanade pokazali da apresijacija nacionalne valute nakon monetarne kontrakcije vodi ka smanjenju izvoza i povećanju uvoza. Goeltom (2008) je istako da relativna snaga kanala deviznog kursa zavisi od režima kursa koji se u zemlji sprovodi. Autor naglašava da da će kanal deviznog kursa biti jači u zemljama sa fleksibilnim deviznim kursom nego u zemljama sa fiksnim deviznim kursom, jer su u slučaju fiksnog deviznog kursa, kretanja kursa ograničena i proizvode slabije efekte na inflaciju i ukupni output i sa dužim vremenskim kašnjenjem (Al-Mashat i Billmeier, 2007). Dennis (2003) je na primeru Australije pokazao da zemlje koje su se opredelile za targetiranje inflacije, prilikom kreiranja optimalne monetarne politike treba da uzmu u obzir uslove trgovine i realni devizni kurs.

\section{Podaci i metodologija}

Za ispitivanje i ocenjivanje transmisionog mehanizma u Srbiji, korišćeno je šest endogenih varijabli: indsutrijska proizvodnja, indeks potrošačkih cena, novčana masa, referentna kamatna stopa, realni efektivni devizni kurs i svetska cena nafte. Industrijska proizvodnja $(\mathrm{Y})$ je korišćena kao pokazatelj ukupne ekonomske aktivnosti i izražena je u indeksnim brojevima uz pretpostavku 2015=100. Kao pokazatelj kretanja inflacije korišćen je indeks potrošačkih cena (CPI, 2006=100). Kao monetarni agregat, korišćena je novčana masa M1, koja je izražena u milionima dinara. Kao faktor tražnje novca korišćena je referentna kamatna stopa (MMR). Realni efektivni devizni kurs (ER) je korišćen kao pokazatelj vrednosti domaće valute, uz napomenu da njegov rast podrazumeva apresijaciju dinara $(2005=100)$. Uticaj eksternih faktora je prikazan putem dejstva svetske cene nafte (OIL), koja je izražena $u$ dolarima po barelu. Raghavan i Silvapulle (2008) su posebno istakli značaj inostranih šokova za male otvorene ekonomije. Podaci o kretanju indeksa industrijske proizvodnje i indeksa potrošačkih cena su preuzeti sa sajta Republičkog zavoda za statistiku. Podaci o kretanju novčane mase, referentne kamatne stope i deviznog kursa su preuzeti sa sajta Narodne banke Srbije, dok su 
(1999) has pointed out that exchange rates and monetary policy are the key instruments of economic management and the stabilization process in developing countries, where the low inflation rate and the international competitiveness are the key economic policy targets. The exchange rate channel, according to Rogoff \& Obstfeld (1995), transmits the effects of monetary policy as follows:

$$
M I \mapsto R \uparrow \mapsto(E) \uparrow \mapsto(N X) I \mapsto Y I
$$

An increase in the value of a domestic currency is represented as E1. This model illustrates that monetary policy leads to an increase in the real exchange rate, while those effects can be transmited to net exports (NX) and total output. On the supply side, the real appreciation of the domestic currency reduces the domestic price of imported goods, which directly reduces domestic inflation by means of the exchange rate pass-through (McCallum and Nelson, 2001). The level of pass-through towards the level of local prices of imported goods and the overall inflation depends on the share of imports, the appreciation magnitude and its timing, and on the macroeconomic characteristics of the national economy (Kara and Ogunc, 2005). For example, Devereux, et al. (2003) have pointed out that national economies with low volatility of money supply have low rates of the exchange rate pass-through channel and vice versa. Vilaret and Palić (2006) have assessed the pass-through effect of the exchange rate on inflation in Serbia. The results of ADL and VAR methodology have shown that the effect of exchange rates on inflation in Serbia is relatively high, but that it is, as in most countries, incomplete and below one.

Although many studies of industrialized countries have shown that a transmission mechanism is not efficient enough (McCarthy, 2007; Burstein, et al, 2002; Campa and Goldberg, 2002), it is still very important for a small open economy (Afandi, 2005; Aslanidi, 2007). Cushman and Zha (1997) have demonstrated on the case of monetary policy in Canada that the appreciation of a national currency after a monetary contraction leads to a decrease in exports and an increase in imports. Goeltom (2008) has pointed out that the relative strength of the exchange rate channel depends on the exchange rate regime which is implemented in a country. The author has stressesed that the exchange rate channel will be stronger in countries with flexible exchange rates than in countries with fixed exchange rates, because fixed exchange rates have limited fluctuations which have less effect on inflation and overall output with longer time delay (Al-Mashat and Billmeier, 2007). Dennis (2003) has shown on the case of Australia that the countries which have opted for inflation targeting, while creating the optimal monetary policy, should take into account the terms of trade and the real exchange rate.

\section{Data and Methodology}

For the purpose of testing and evaluating the transmission mechanism in Serbia, six endogenous variables have been used: industrial production, consumer price index, money supply, reference interest rate, the real effective exchange rate and the world oil price. Industrial production $(Y)$ is used as an indicator of overall economic activity and is expressed in index numbers assuming that $2015=100$. As an indicator of inflation, the consumer price index $(C P I, 2006=100)$ has been used. As a monetary aggregate, money supply M1 has been used, expressed in millions of the local currency (in million dinars). The reference interest rate (MMR-money market rate) has been used as a factor of money demand and the real effective exchange rate $(E R)$ has been used as an indicator of the domestic currency value, noting that its growth implies the appreciation of the dinar $(2005=100)$. The influence of external factors is shown through the impact of the world oil price $(O I L)$, which is expressed in dollars per barrel. Raghavan \& Silvapulle (2008) have particularly stressed the importance of foreign shocks in small open economies. The data on the trends in the industrial production index and consumer price index are taken from the Statistical Office of the Republic of Serbia website. The data on the trends in money supply, the reference interest rate and the exchange rates are taken from the website of the National Bank of Serbia, while the data on the trends in world oil prices are taken from the US Energy Information 
podaci o kretanju svetske cene nafte preuzeti sa US. Energy Information Administration. Vremenski okvir posmatranja varijabli obuhvata period 2007 M01- 2015 M12, tako da se raspolaže sa ukupno 108 opservacija. Sve varijable izuzev referentne kamatne stope $\mathrm{su}$, iz statističkih razloga, konvertovane $\mathrm{u}$ logaritamski oblik (L).

$\mathrm{U}$ ispitivanju efekata transmisionog mehanizma uglavnom se koristi VAR ili SVAR model, ali zbog brojnih prednosti, kao što su identifikovanje parametara modela i uticaja strukturnih šokova $\mathrm{u}$ analizi simultanih interakcija među varijablama, u radu će biti sproveden SVAR model. Osnovni SVAR model se može prikazati u sledećem obliku:

$$
\mathrm{A}_{0} \mathrm{y}_{\mathrm{t}}=\mathrm{c}_{0}+\mathrm{A}_{1} \mathrm{y}_{\mathrm{t}-1}+\mathrm{A}_{2} \mathrm{y}_{\mathrm{t}-2}+\ldots+\mathrm{A}_{\mathrm{p}} \mathrm{y}_{\mathrm{t}-\mathrm{p}}+\mathrm{D}+\mathrm{v}_{\mathrm{t}}(3)
$$

gde je $y_{t}(n \times 1)$, vektor endogenih varijabli, $c_{0}$ je $(n \times 1)$, vektor konstanti, $A_{i}$ je $(n \times n)$ matrica $(i=0$, ..., p), strukturnih parametara, $D$ je $(n \times 1)$, vektor egzogenih varijabli, a $v_{t}$ su ( $\left.n \times 1\right)$, strukturne inovacije, koje su ortogonalne, odnosno međusobno nekorelisane. Za sprovođenje ovog modela na primeru Republike Srbije, kao polazna osnova je korišćen model koji su razvili Kim i Roubini (2000) u studiji u kojoj su ispitivali efekte monetarne politike u otvorenoj ekonomiji, primenom nerekurzivnog SVAR modela za nonU.S. G-7 ekonomije. Šematski, model se može prikazati na sledeći način:

$$
\left[\begin{array}{c}
e_{l y s a} \\
e_{l c p i} \\
e_{l m 1} \\
e_{m m r} \\
e_{l e r} \\
e_{\text {loil }}
\end{array}\right]=\left[\begin{array}{cccccc}
1 & 0 & 0 & 0 & 0 & g_{16} \\
g_{21} & 1 & 0 & 0 & 0 & g_{26} \\
g_{31} & g_{32} & 1 & g_{34} & 0 & 0 \\
0 & 0 & g_{43} & 1 & g_{45} & g_{46} \\
g_{51} & g_{52} & g_{53} & g_{54} & 1 & g_{56} \\
0 & 0 & 0 & 0 & 0 & 1
\end{array}\right]\left[\begin{array}{c}
u_{l y s a} \\
u_{l c p i} \\
u_{l m 1} \\
u_{m m r} \\
u_{l e r} \\
u_{l o i l}
\end{array}\right]
$$

Važno je napomenuti da je u modelu prisutno 16 nultih ograničenja, i da se za nivo identifikovanosti korsiti obrazac $\left(n^{2}-n\right) / 2$, što će reći da je u sistemu sa šest varijabli 15 ograničenja potrebno za tačnu identifikovanost, a sva ograničenja preko toga (kao što je u ovom slučaju) čine sistem prekomerno identifikovanim. U prikazanoj matrici, $e_{\text {lyssa' }}$ $e_{l c p i^{\prime}} e_{l m 1^{\prime}} e_{m m r^{\prime}} e_{l e r}$ i $e_{\text {loil }}$ predstavljaju strukturne poremećaje, kao što su šokovi industrijske proizvodnje, indeksa potrošačkih cena, novčane mase, tražnje za novcem, deviznog kursa i šoka na naftnom tržištu, respektivno, dok $u_{l y s a^{\prime}} u_{l c p i^{\prime}}$ $u_{l m 1^{\prime}} u_{m m r^{\prime}} u_{\text {ler }}$ i $u_{\text {loil }}$ su reziduali u redukovanoj formi jednačine, i predstavljaju neočekivana kretanja svake od varijabli. Inostrani sektor karakteriše jedna varijabla, i to svetska cena nafte, dok nacionalnu ekonomiju reprezentuje pet varijabli. Dve varijable se odnose na tržište proizvodnje (industrijska proizvodnja i indeks potrošačkih cena), tržište novca oslikavaju takođe dve varijable (referentna kamatna stopa i monetarni agregat), a finansijsko tržište reprezentuje devizni kurs. U modelu su prisutne sledeće pretpostavke: na nivo ekonomske aktivnosti i inflacije deluju monetarne varijable sa izvesnim kašnjenjem, dok istovremeni uticaj vrši kretanje svetske cene nafte, budući da je ono veoma značajno u sektoru proizvodnje, odnosno realna sfera ekonomije reaguje na monetarne i finansijske signale posle izvesnog perioda kašnjenja.

\section{Empirijski rezultati}

Na bazi prethodno opisane metodologije, rezultat istraživanje sastojaće se od sledećih koraka:

1. Određivanje optimalne docnje $\mathrm{u}$ skladu sa informacionim kriterijumima i obezbeđivanje stabilnosti SVAR modela;

2. Ocenjivanje koeficijenata u okviru matrice kratkoročnih koeficijenata;

3. Deskripcija rezultata funkcije impulsnog odziva, i;

4. Pojašnjenje rezultata dekompozicije varijanse. Određivanje optimalne dužine kašnjenja je veoma značajan faktor $\mathrm{u}$ implementiranju modela, jer u velikoj meri može uticati i na rezultate modela. U literaturi su se izdvojili specifični informacioni kriterijumi koji sugerišu odgovarajući broj docnji u modelu, i oni po nekom pravilu ne sugerišu identičan broj docnji. Takav slučaj je i u Tabeli 1 . Razlika u informacionim kriterijumima se svodi na različit način "kažnjavanja" zbog prisustva većeg broja parametara u modelu. U ekonometrijskoj literaturi Acquah (2012), prednost u odnosu na ostale kriterijume dobija Schwarz informacioni kriterijum (SC). Na osnovu toga, u radu će se kao optimalna dužina kašnjenja koristiti docnja 1 , odnosno period kašnjenja od mesec dana. 
Administration. The time framework for observing the variables ranges from 2007 M01 to $2015 \mathrm{M} 12$, hence there are 108 observations. All the variables except for reference interest rates are, for statistical reasons, converted to logarithmic form $(L)$.

In examining the effects of the transmission mechanism, the VAR and SVAR models are most commonly used but because of the many advantages, such as the identification of the model parameters and the impact of structural shocks in the simultaneous analysis of interactions between variables, the SVAR model will be carried out. The basic SVAR model can be represented in the following form:

$$
\mathrm{A}_{0} \mathrm{y}_{\mathrm{t}}=\mathrm{c}_{0}+\mathrm{A}_{1} \mathrm{y}_{\mathrm{t}-1}+\mathrm{A}_{2} \mathrm{y}_{\mathrm{t}-2}+\ldots+\mathrm{A}_{\mathrm{p}} \mathrm{y}_{\mathrm{t}-\mathrm{p}}+\mathrm{D}+\mathrm{v}_{\mathrm{t}}(3)
$$

wherein $y_{t}\left(\begin{array}{lll}n & x & 1\end{array}\right)$ is a vector of endogenous variables, $c_{0}$ is $(n \times 1)$ is a vector of constants, $A_{i}$ is $(n \times n)$ a matrix $(i=0, \ldots, p)$ of structural parameters, $D$ is $(n \times 1)$ is a vector of exogenous variables and $v_{t}$ are $(n \times 1)$ structural innovations, which are orthogonal, i.e. mutually uncorrelated. For the implementation of this model on the case of the Republic of Serbia, a model developed by Kim \& Roubini (2000) has been used. These authors examined the effects of monetary policy in an open economy where the non-recursive SVAR model for non-US G-7 economy was used as a starting point. Schematically, the model can be represented as follows:

$$
\left[\begin{array}{c}
e_{l y s a} \\
e_{l c p i} \\
e_{l m 1} \\
e_{m m r} \\
e_{l e r} \\
e_{l o i l}
\end{array}\right]=\left[\begin{array}{cccccc}
1 & 0 & 0 & 0 & 0 & g_{16} \\
g_{21} & 1 & 0 & 0 & 0 & g_{26} \\
g_{31} & g_{32} & 1 & g_{34} & 0 & 0 \\
0 & 0 & g_{43} & 1 & g_{45} & g_{46} \\
g_{51} & g_{52} & g_{53} g_{54} & 1 & g_{56} \\
0 & 0 & 0 & 0 & 0 & 1
\end{array}\right]\left[\begin{array}{c}
u_{l y s a} \\
u_{l c p i} \\
u_{l m 1} \\
u_{m m r} \\
u_{l e r} \\
u_{\text {loil }}
\end{array}\right]
$$

It is important to note that in the present model there are 16 zero limits, and that for the level of identification a form $\left(n^{2}-n\right) / 2$ is used which means that in the system of six variables there are 15 limits necessary for accurate identification and any limit above that number (like in this case) makes the system overidentified. In the presented matrix, $e_{l y s a}, e_{l c p i}$, $e_{l m 1}, e_{m m r}, e_{l e r}$ and $e_{\text {loil }}$ are structural disorders such as industrial production shocks, shocks in consumer price index, money supply, money demand, exchange rate and on the oil market, retrospectively, while $u_{l y s a}, u_{l c p i}, u_{l m 1}, u_{m m r}, u_{l e r}$ and $u_{\text {loil }}$ are residuals in the reduced equation form, and they represent the unexpected movements of each variable. The external sector is characterized by one variable, the world price of oil, while the national economy is represented by five variables. Two variables are related to market production (industrial production and consumer price index), money market is related to two variables (reference interest rate and monetary aggregate), and the financial market is represented by the exchange rate. The present model is based on the following assumptions: the level of economic activity and inflation are under the influence of monetary variables with certain delays, while a simultaneous influence is exerted by the movements of the world oil prices, since they are very important in the manufacturing sector, i.e. the real sector of the economy responds to monetary and financial signals after a certain period of delay.

\section{Empirical Results}

Based on the methodology described above, the results of the research can be divided into following steps:

1. Determination of the optimal lag length in accordance with the information criteria and the stability of the model;

2. Evaluation of the coefficients in the matrix of short-term coefficients;

3. Description of the results of the impulse response function, and

4. Explanation of the results of the variance decomposition.

The determination of optimal lag length is an important factor in implementing the model, since it can have a great influence on the results of the model. The reference literature provides special information criteria which suggest an adequate number of lags in a model. However, they do not suggest the identical number of lags. Such a case is given in Table 1. The difference in information criteria boils down to the different ways of "punishment" when there is a greater number of parameters in a model. The econometric literature (Acquah, 2012) gives advantage to the Schwarz information criterion (SC). Consequently, this paper uses the optimal lag length with value 1 . 
Tabela 1. Izbor optimalne docnje u VAR modelu

\begin{tabular}{|c|c|c|c|c|c|c|}
\hline \multicolumn{7}{|c|}{ Endogene varijable: LYSA LCPI LM MMR LER LOIL } \\
\hline \multicolumn{7}{|c|}{ Egyogene varijable: C DUM } \\
\hline \multicolumn{7}{|c|}{ Uzorak: 2007M01 2015M12 } \\
\hline Docnja & $\log L$ & LR & FPE & AIC & SC & HQ \\
\hline 0 & 248.0348 & NA & $3.18 \mathrm{e}-10$ & -4.840696 & -4.684386 & -4.777434 \\
\hline 1 & 1036.236 & 1466.055 & $9.33 \mathrm{e}-17$ & -19.88473 & $-18.79056^{*}$ & -19.44190 \\
\hline 2 & 1106.576 & 122.3910 & $4.73 \mathrm{e}-17^{*}$ & -20.57152 & -18.53949 & $-19.74912^{*}$ \\
\hline 3 & 1133.724 & 43.97997 & $5.76 \mathrm{e}-17$ & -20.39448 & -17.42459 & -19.19251 \\
\hline 4 & 1180.805 & $70.62204^{*}$ & $4.79 \mathrm{e}-17$ & $-20.61611^{*}$ & -16.70835 & -19.03457 \\
\hline
\end{tabular}

*označava optimalan broj docnji prema odgovarajućem informacionom kriterijumu. LR test statistika na nivou od 5\%, FPE konačna greška predviđanja, AIC Akaike informacioni kriterijum, SC Švarc informacioni kriterijum, HQ Hanan Kvin informacioni kriterijum. Izvor: kalkulacija autora

Kako bi se potvrdila optimalnost ovog izbora testirana je stabilnost modela, kao i prisustvo (odsustvo) autokorelacije reziduala u Tabeli 2 i Slici 1. Budući da nije odbijena nulta hipoteza o odsustvu autokorelacije, kao i da se karakteristične vrednosti nalaze unutar jediničnog kruga, može se reći da je prilikom odabira VAR (1) modela, on stabilan i oslobođen prisustva serijske korelacije.

Tabela 2. Autokorelacija reziduala u VAR (1) modelu

\begin{tabular}{|c|c|c|}
\hline \multicolumn{3}{|c|}{$\mathrm{H}_{0}$ : Ne postoji autokorelacija na nivou docnje 1 } \\
\hline Uzorak 2007M01 2015M12 \\
\hline Docnja & LM statistika & Verovatnoća \\
\hline 1 & 45.45001 & 0.1344 \\
\hline
\end{tabular}

Izvor: kalkulacija autora

Slika 1. Stabilnost VAR (1) modela

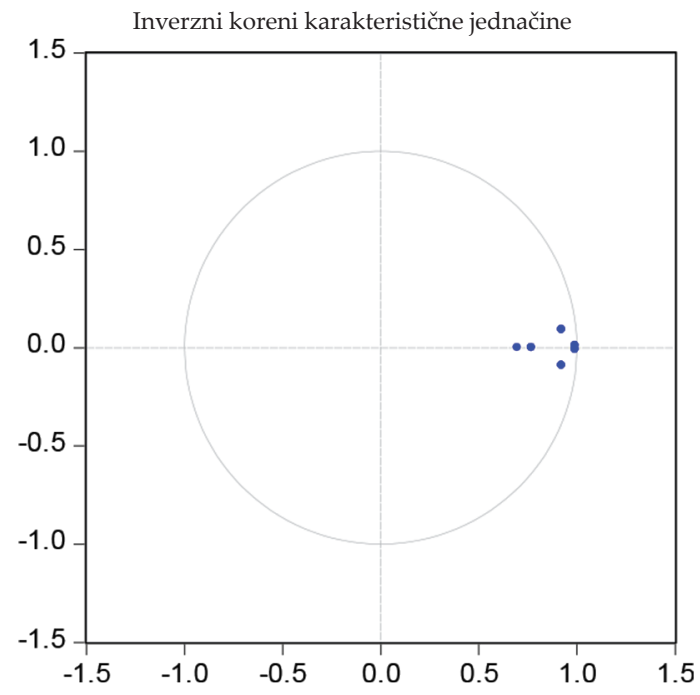

Izvor: kalkulacija autora
Ocenjeni kratkoročni koeficijenti su prikazani u Tabeli 3, a osenčene vrednosti su i statistički značajne na nivou od 5\%. Model je prekomerno identifikovan, a ograničenja su validna pod nultom hipotezom LR testa za prekomernu identifikaciju. SVAR model je prekomerno identifikovan sa vrednošću verodostojnosti (log likelihood) 1073.610, pri čemu nulta hipoteza nije odbijena na 5\%

Model ukazuje da depresijacija deviznog kursa dovodi do rasta ekonomske aktivnosti. Ovaj efekat se može objasniti uticajem depresijacije kursa na rast izvoza nacionalne ekonomije, čime se povećava ukupna agregatna tražnja i time privredna aktivnost u nacionalnoj ekonomiji. Inverzna relacija deviznog kursa i inflacije, može se objasniti time da depresijacija valute utiče $i$ na rast cena $u$ nacionalnoj ekonomiji, odnosno da je u cilju stabilizacije cena potrebno apresirati devizni kurs. Kretanje na inostranom tržištu, skok cene nafte, preko uticaja na domaću inflaciju ima negativan efekat i na devizni kurs. Ostali rezultati su u skladu sa onim što sugeriše ekonomska teorija (npr. negativan odnos novčane mase i kamatne stope), ali nisu statistički značajni. 
Table 1. The selected optimal lag length in the VAR model

\begin{tabular}{|c|c|c|c|c|c|c|}
\hline \multicolumn{7}{|c|}{ Endogenous variable: LYSA LCPI LM MMR LER LOIL } \\
\hline \multicolumn{7}{|c|}{ Exogenous variable: $\mathrm{C}$ DUM } \\
\hline \multicolumn{7}{|c|}{ Sample: 2007M01 2015M12 } \\
\hline Lags & LogL & LR & FPE & AIC & SC & HQ \\
\hline 0 & 248.0348 & NA & $3.18 \mathrm{e}-10$ & -4.840696 & -4.684386 & -4.777434 \\
\hline 1 & 1036.236 & 1466.055 & $9.33 \mathrm{e}-17$ & -19.88473 & $-18.79056^{*}$ & -19.44190 \\
\hline 2 & 1106.576 & 122.3910 & $4.73 \mathrm{e}-17^{*}$ & -20.57152 & -18.53949 & $-19.74912^{*}$ \\
\hline 3 & 1133.724 & 43.97997 & $5.76 \mathrm{e}-17$ & -20.39448 & -17.42459 & -19.19251 \\
\hline 4 & 1180.805 & $70.62204^{*}$ & $4.79 \mathrm{e}-17$ & $-20.61611^{*}$ & -16.70835 & -19.03457 \\
\hline
\end{tabular}

* Signifies the optimal lag length according to the information criterion. LR test statistics with 5\% level, FPE Final prediction error, AIC Akaike information criterion, SC Schwarz information criterion, HQ Source: author's calculations

In order to confirm the optimality of this choice, we have tested the model's stability and the (non-)existence of residual autocorrelation (Table 2 and Figure 1). Since the null hypothesis about the non-existence of autocorrelation cannot be rejected and that the characteristic values are within the unit circle, we can say that the VAR (1) model is stable and free of serial correlation.

Table 2. Autocorrelation of residuals in the VAR (1) model

\begin{tabular}{|c|c|c|}
\hline \multicolumn{3}{|l|}{$\mathrm{H}_{0}$ : No autocorrelation } \\
\hline Sample 2007M01 2015M12 \\
\hline Lag & LM statistic & Probability \\
\hline 1 & 45.45001 & 0.1344 \\
\hline
\end{tabular}

Source: author's calculations

Figure 1. Stability of the VAR (1) model

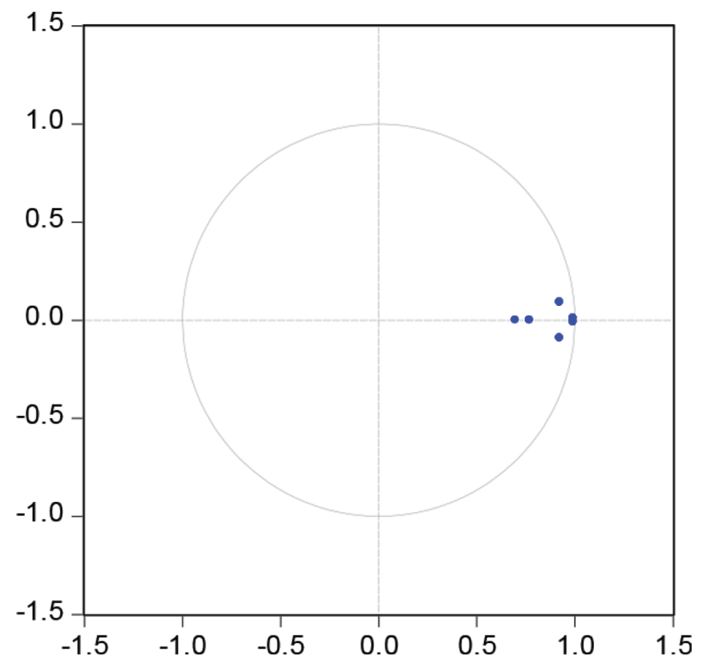

Source: author's calculations
The estimated short-term coefficients are shown in Table 3. The shaded values are statistically significant at the $5 \%$ level. The model is over-identified and the restrictions are valid under the null hypothesis with LR test of over-identification. The SVAR model is over-identified with the value of credibility (log likelihood) of 1073.610, where the null hypothesis is not rejected at the $5 \%$.

The model suggests that the exchange rate depreciation leads to the growth in economic activity. This effect can be explained by the impact the exchange rate depreciation has on the export growth in the national economy, which increases the overall aggregate demand and consequently economic activity in the national economy. The inverse relation between the exchange rate and inflation can be explained by the fact that the currency depreciation affects the price growth in the national economy, and that it is necessary to appreciate the exchange rates in order to stabilize the prices. The movements in the international market and the oil prices, through the impact they have on domestic inflation, have a negative effect on exchange rates. The other results are consistent with what economic theory suggests (e.g. the negative relation of money supply and interest rates), but they are not statistically significant. 
Tabela 3. Ocenjeni kratkoročni koeficijenti

\begin{tabular}{|l|c|c|c|c|c|c|}
\hline & LYSA & LCPI & LM1 & MMR & LER & LOIL \\
\hline LYSA & 1 & & & & & $-0.006(0.04)$ \\
\hline LCPI & $-0.018(0.02)$ & 1 & & & & $-0.01(0.008)$ \\
\hline LM1 & $0.3(0.28)$ & $2.24(1.63)$ & 1 & $-0.11(0.11)$ & & \\
\hline MMR & & & $22.14(18.57)$ & 1 & $13.89(40.62)$ & $1.82(1.84)$ \\
\hline LER & $-0.09(0.04)$ & $-0.43(0.21)$ & $-0.06(0.18)$ & $-0.002(0.006)$ & 1 & $-0.06(0.025)$ \\
\hline LOIL & & & & & & 1 \\
\hline
\end{tabular}

Vrednosti u zagradama označavaju standardnu grešku, dok se vrednosti izvan odnose na ocenjene koeficijente.

Izvor: kalkulacija autora

Slika 2. Funkcija impulsnog odziva
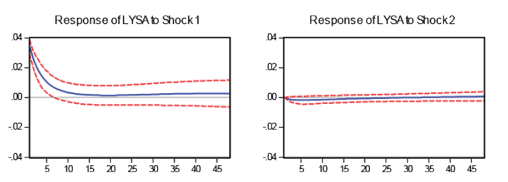

Response to Structural One S.D. Innovations \pm 2 S.E.
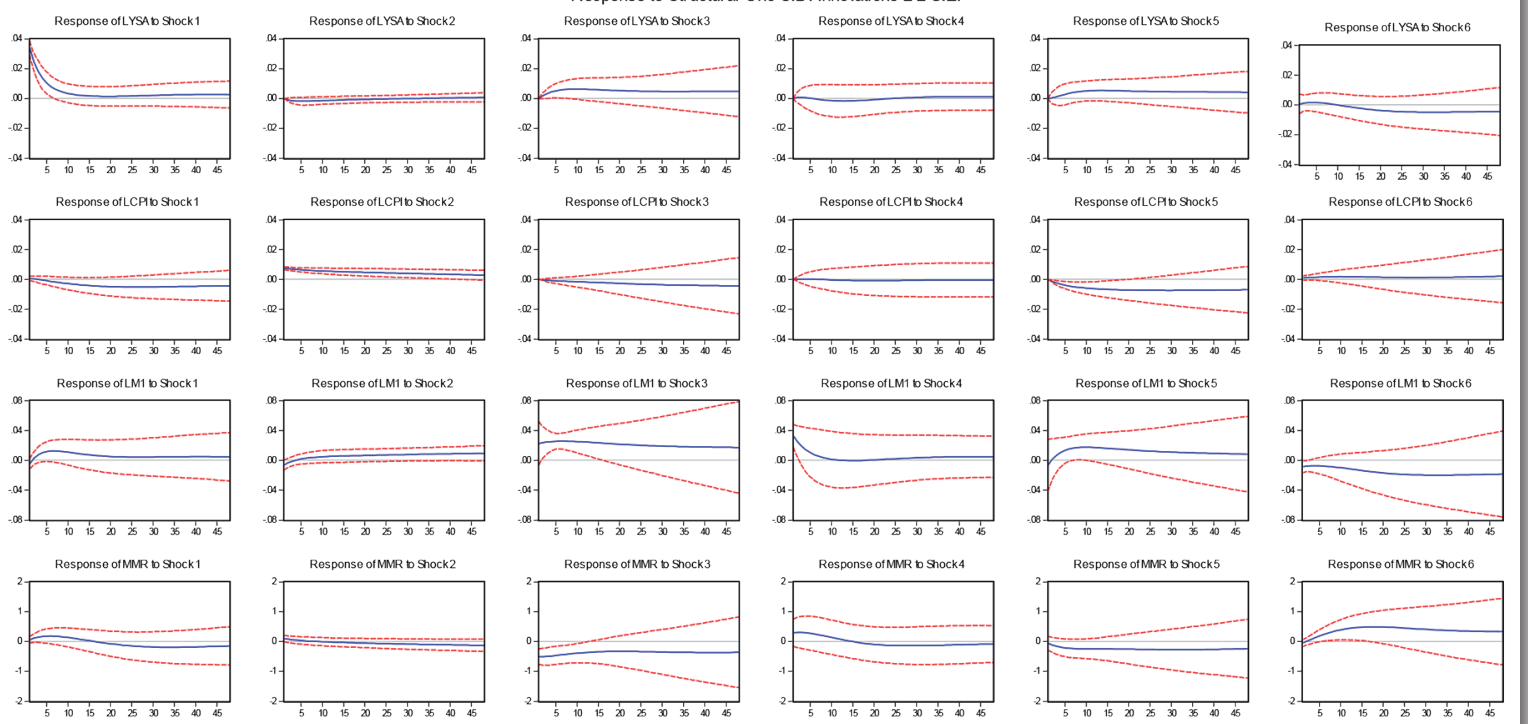

Response ofmMR to Shock 6
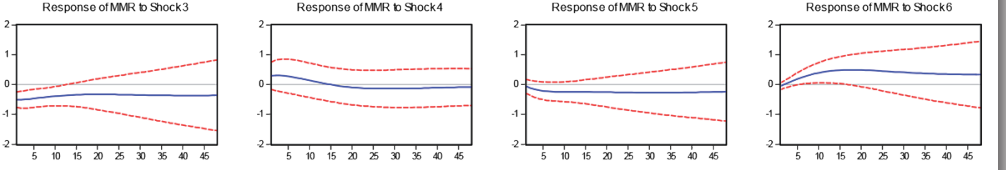

Response oftLR b STiock1
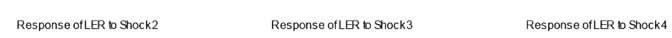

Response ofLER is Shock5
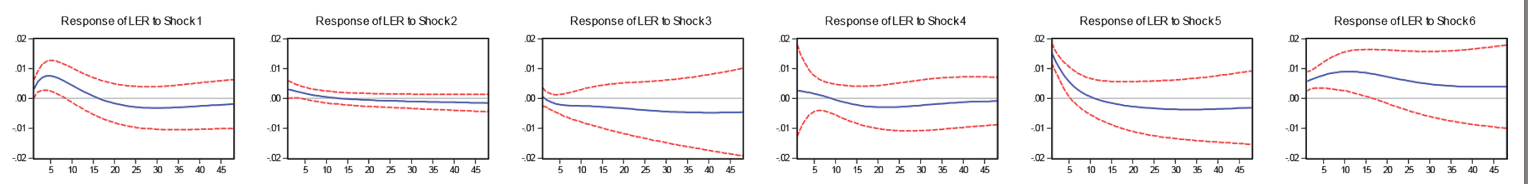

Response ofl.Ll. b Sthock1

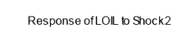

Response of Loll b S Shock3
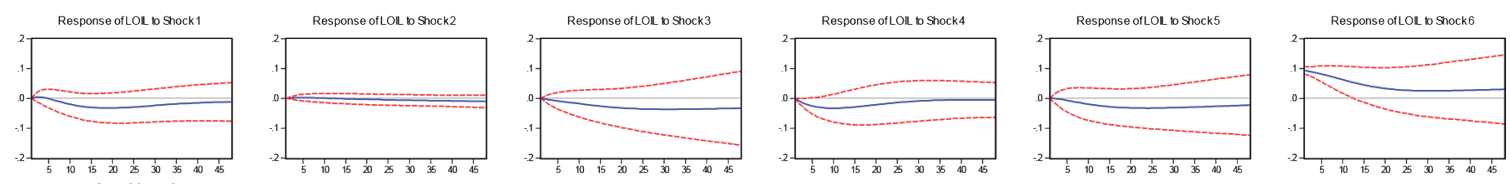

Izvor: kalkulacija autora

Na Slici 2 je prikazana ocenjena funkcija impulsnog odziva. Ona pokazuje impulsne odzive (u periodu nakon 4 godine) na pozitivan šok varijable od interesa $u$ vrednosti dve standardne devijacije. U slučaju pozitivnog šoka u privrednoj aktivnosti, prisutan je statistički značajan uticaj u prvoj godini na pozitivno kretanje novčane mase, kao i apresijaciju deviznog kursa. Rast cena, odnosno šok u kretanju cena, utiče na pad novčane mase, ali nema uticaj na rast kamatnih stopa. Šok u novčanoj masi, tzv. monetarna ekspanzija ima pozitivan uticaj na ekonomsku aktivnost, i on je statistički značajan i nakon jedne godine. Sa druge strane, šok u kamatnoj stopi, odnosno monetarna kontrakcija, ima negativan uticaj na novčanu masu, i dolazi do umirivanja privredne aktivnosti, bez značajnijeg uticaja na kretanje cena (postoji li price puzzle u Srbiji?). Šok u deviznom kursu, odnosno njegova apresijacija ima statistički značajan uticaj na pad inflacije. Šok u svetskoj ceni nafte nema značajniji uticaj na kretanja varijabli u privredi Srbije.

U Tabelama 4 i 5 su prikazani izvori 
Table 3. The estimated short-term coefficients

\begin{tabular}{|l|c|c|c|c|c|c|}
\hline & LYSA & LCPI & LM1 & MMR & LER & LOIL \\
\hline LYSA & 1 & & & & & $-0.006(0.04)$ \\
\hline LCPI & $-0.018(0.02)$ & 1 & & & & $-0.01(0.008)$ \\
\hline LM1 & $0.3(0.28)$ & $2.24(1.63)$ & 1 & $-0.11(0.11)$ & & \\
\hline MMR & & & $22.14(18.57)$ & 1 & $13.89(40.62)$ & $1.82(1.84)$ \\
\hline LER & $-0.09(0.04)$ & $-0.43(0.21)$ & $-0.06(0.18)$ & $-0.002(0.006)$ & 1 & $-0.06(0.025)$ \\
\hline LOIL & & & & & & 1 \\
\hline
\end{tabular}

The values given in brackets signify the standard error while the values without brackets represent the estimated coefficients. Source: author's calculations

Figure 2. Impulse response function
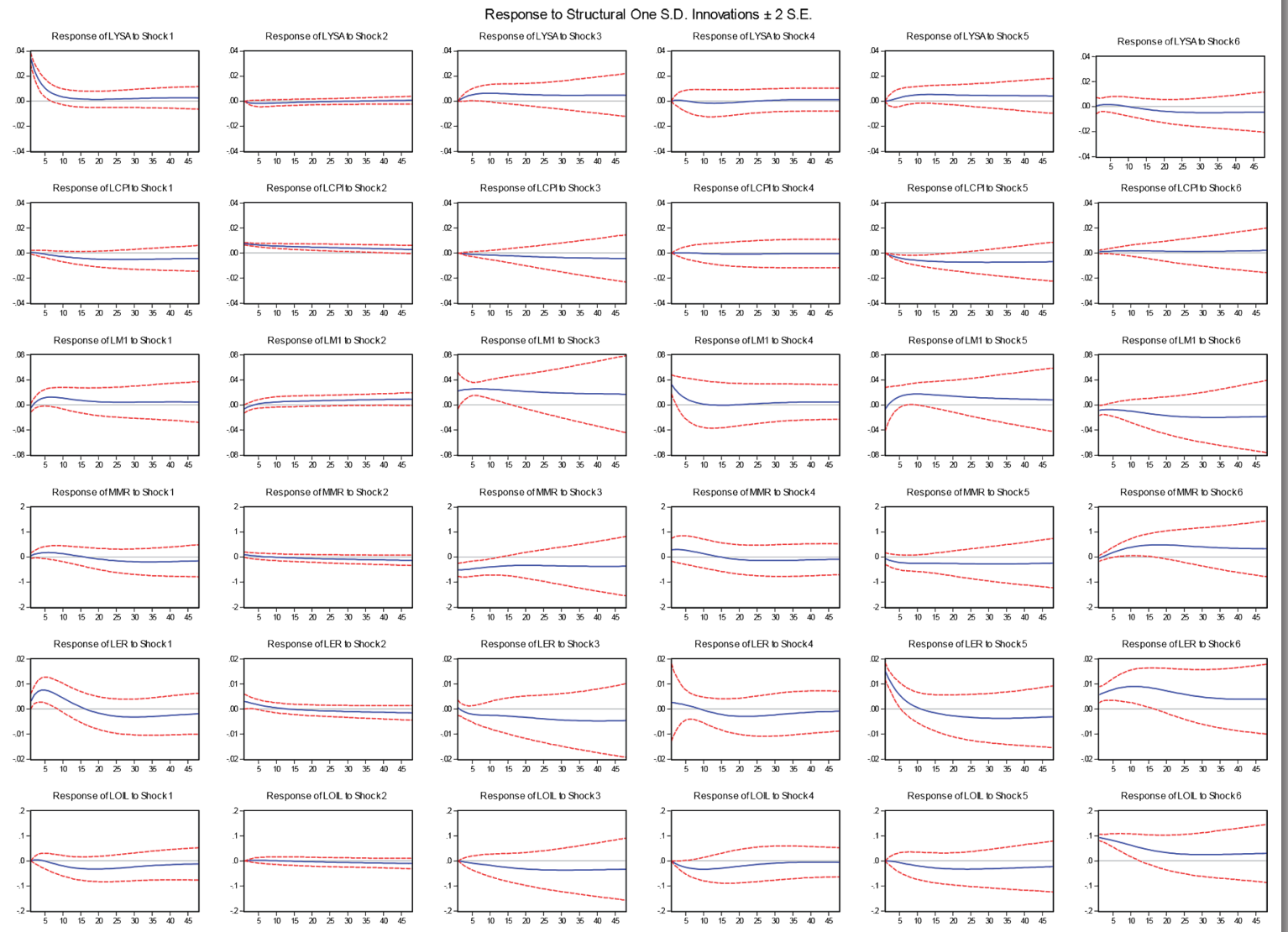

Source: author's calculations

Figure 2 shows the estimated impulse response function. It shows the impulse response (in the period after 4 years) on selected positive shock variables with the value of two standard deviations. In the case of a positive shock in economic activity, there is a statistically significant effect in the first year on a positive trend in money supply, as well as in the exchange rate appreciation. The price increase, i.e. a shock in price movements, causes a drop in money supply, but has no effect on the growth of interest rates. Shocks in the money supply, the so-called monetary expansions, have a positive impact on economic activity which is statistically significant after one year. On the other hand, a shock in the interest rate or a monetary contraction, has a negative impact on money supply, and makes economic activity steadier, with no significant impact on price movements (is there a price puzzle in Serbia?). A shock in the exchange rate, and its appreciation, have a statistically significant impact on the inflation decline. A shock in the global prices of oil does not have a significant 
fluktuacija realnih varijabli, indeksa industrijske proizvodnje i indeksa potrošačkih cena. U Tabeli 4 je prikazana dekompozicija varijanse ukupne ekonomske aktivnosti, a u Tabeli 5 indeks potrošačkih cena. Nakon četiri godine, šokovi sopstvene veličine najviše objašnjavaju fluktuacije outputa, ali je važno istaći i nivo novčane mase, koji učestvuje sa $21.93 \%$, kao i kanal deviznog kursa koji učestvuje sa skoro $17 \%$ u objašnjavanju ukupnih fluktuacija privredne aktivnosti. Na fluktuacije potrošačkih cena, pored doprinosa sopstvene veličine, nakon četiri godine najviše utiče kanal deviznog kursa sa preko $45 \%$, čime se potrvrđuje teza da u Srbiji, kanal deviznog kursa predstavlja najznačajniji kanal transmisije. Zanimljivo je istaći da i u jednom, i u drugom slučaju kanala kamatne stope (referentna kamatna stopa) učestvuje sa manje od jednog procenta $u$ objašnjavanju fluktuacija realnih veličina. Evidentno je da ovaj kanal, za razliku od razvijenih zemalja slabo razvijen u Srbiji.

konkurentnosti, odnosno rast izvoza, potrebno smanjiti vrednost domaće valute, što u krajnjoj instanci ima efekat na rast agregatne tražnje. Inverzna relacija deviznog kursa i inflacije, može se objasniti time da depresijacija valute utiče i na rast cena u nacionalnoj ekonomiji, odnosno da je u cilju stabilizacije cena potrebno apresirati devizni kurs. Kretanje na inostranom tržištu, skok cene nafte, preko uticaja na domaću inflaciju ima negativan efekat i na devizni kurs.

Imajući u vidu istraživačka pitanja koja su u radu postavljena, važno je istaći sledeće:

i. Od monetarnih šokova veoma značajan uticaj na kretanje i fluktuacije u outputu ima novčana masa (ponuda novca), što je potvrđeno i na osnovu funkcije impulsnog odziva i dekompozicije varijanse. Na osnovu ovoga se može reći da monetarna ekspanzija ima pozitivne efekte na ekonomsku aktivnost u Srbiji;

ii. Iovom analizom je potvrđeno da deviznikurs predstavlja najznačajniji kanal transmisije u Srbiji. To je naročito

Tabela 4. Dekompozicija varijanse ekonomske aktivnosti

\begin{tabular}{|c|c|c|c|c|c|c|}
\hline Period & LYSA & LCPI & LM1 & MMR & LER & LOIL \\
\hline 12 & 82.55 & 0.81 & 10.44 & 0.38 & 5.36 & 0.46 \\
\hline 24 & 65.36 & 0.79 & 17.36 & 0.67 & 12.19 & 3.63 \\
\hline 36 & 54.79 & 0.66 & 19.99 & 0.72 & 15.19 & 8.64 \\
\hline 48 & 47.94 & 0.62 & 21.93 & 0.93 & 16.79 & 11.78 \\
\hline
\end{tabular}

Izvor: kalkulacija autora

Tabela 5. Dekompozicija varijanse indeksa potrošačkih cena

\begin{tabular}{|c|c|c|c|c|c|c|}
\hline Period & LYSA & LCPI & LM1 & MMR & LER & LOIL \\
\hline 12 & 5.58 & 23.63 & 2.04 & 0.10 & 30.05 & 3.87 \\
\hline 24 & 14.52 & 28.52 & 4.52 & 0.40 & 40.26 & 2.94 \\
\hline 36 & 17.73 & 37.35 & 7.34 & 0.35 & 43.67 & 2.40 \\
\hline 48 & 18.33 & 58.36 & 9.94 & 0.29 & 45.15 & 2.65 \\
\hline
\end{tabular}

Izvor: kalkulacija autora

\section{Zaključna razmatranja}

U ovom radu je ispitivana efikasnost kanala transmisije u Srbiji, primenom nerekurzivnog SVAR modela, dok je vremenski horizont posmatranja bio 2007 M01-2015 M12. U posebnom fokusu analize su se našli "money view" kanali (devizni kurs i referentna kamatna stopa). Na bazi definisane matrice, ustanovljeno je da depresijacija deviznog kursa dovodi do rasta ekonomske aktivnosti. Ovakav rezultat je u skladu sa intencijom da je za podizanje vidljivo posmatrajući funkciju impulsnog odziva i efekat apresijacije kursa na snižavanje inflacije. Takođe, dekompozicijom varijanse indeksa potrošačkih cena je ustanovljeno da je efekat deviznog kursa nakon četiri godine preko 45\% u ukupnoj fluktuaciji cena; iii. Efekat referentne kamatne stope u Srbiji je, prema rezultatima istraživanja, praktično zanemarljiv. Posmatranje funkcije impulsnog odziva je pokazalo da ni inflacija ne reaguje na pozitivan šok u referentnoj stopi, i može se suditi o izvesnom price puzzle mehanizmu u Srbiji

iv. Kao pokazatelj eksternih šokova, uključeno je kretanje svetske cene i pokazano je da ono nema značajniji efekat od domaćih šokova, ali i da treba istaći njeno učešće u fluktuaciji ukupnog outputa sa skoro $12 \%$.

Makroekonomske implikacije ovako dobijenih rezultata se odnose na činjenicu da monetarne vlasti mogu upravljanjem 
impact on the movement of the variables in the Serbian economy.

Tables 4 and 5 feature the sources of fluctuations in real variables, the index of industrial production and the consumer price index. Table 4 presents the variance decomposition of the overall economic activity, and Table 5 of the CPI. After four years, the shocks of their own size best describe the fluctuations in output, but it is important to indicate the importance of money supply, which accounts for $21.93 \%$, and the exchange rate channel, which accounts for almost $17 \%$ in the total fluctuations of economic activity. Fluctuations in consumer prices are, in addition to their own contribution size, after four years most influenced by the exchange rate channel with over $45 \%$, which confirms the hypothesis that in Serbia the exchange rate channel is the most important channel of transmission. It is interesting to point out that in the first, and in the second case, the interest rate channel (i.e. the reference interest rate) accounts for less than one percent in the fluctuations of real values. It is evident that this channel, in contrast to developed countries, is still poorly developed in Serbia. interest rate). On the basis of the defined matrix, it has been found that the exchange rate depreciation leads to an increase in economic activity. This result is consistent with the suggestions that an increase in competitiveness and export growth requires a reduction in the value of the domestic currency, which ultimately has an effect on the growth in aggregate demand. The inverse relation between the exchange rate and inflation can be explained by the fact that the currency depreciation affects the price growth in the national economy, and that in order to stabilize the prices it is necessary to appreciate the exchange rate. The movements in the international market and oil prices, through their impact on domestic inflation, have a negative effect on exchange rates. Taking into consideration our research question, it is important to emphasize the following conclusions:

i. Of all monetary shocks, the most influential one in terms of output fluctuations and movement is money supply, which is confirmed based on the impulse response function and variance decomposition. Consequently, it can be said that the monetary expansion has positive effects on economic activities in Serbia.
Table 4. Variance decomposition of the industrial production

\begin{tabular}{|c|c|c|c|c|c|c|}
\hline Period & LYSA & LCPI & LM1 & MMR & LER & LOIL \\
\hline 12 & 82.55 & 0.81 & 10.44 & 0.38 & 5.36 & 0.46 \\
\hline 24 & 65.36 & 0.79 & 17.36 & 0.67 & 12.19 & 3.63 \\
\hline 36 & 54.79 & 0.66 & 19.99 & 0.72 & 15.19 & 8.64 \\
\hline 48 & 47.94 & 0.62 & 21.93 & 0.93 & 16.79 & 11.78 \\
\hline
\end{tabular}

Source: author's calculations

Table 5. Variance decomposition of the consumer price index

\begin{tabular}{|c|c|c|c|c|c|c|}
\hline Period & LYSA & LCPI & LM1 & MMR & LER & LOIL \\
\hline 12 & 5.58 & 23.63 & 2.04 & 0.10 & 30.05 & 3.87 \\
\hline 24 & 14.52 & 28.52 & 4.52 & 0.40 & 40.26 & 2.94 \\
\hline 36 & 17.73 & 37.35 & 7.34 & 0.35 & 43.67 & 2.40 \\
\hline 48 & 18.33 & 58.36 & 9.94 & 0.29 & 45.15 & 2.65 \\
\hline
\end{tabular}

Source: author's calculations

\section{Conclusions}

This paper has examined the efficiency of the transmission channel in Serbia by using the nonrecursive SVAR model with the time interval of observation ranging from 2007 M01 - 2015 M12. The special emphasis has been on "money view" channels (i.e. the exchange rate and reference ii. This analysis confirms that the exchange rate is the most significant transmission channel in Serbia. It is most obviously seen when the impulse response function and the exchange rate appreciation effects on inflation reduction are being observed. Moreover, the variance decomposition of the consumer price index shows that the effects of exchange rates after four years account for over $45 \%$ of price fluctuations.

iii. The effects of the reference interest rate in Serbia are almost negligible. The impulse response function reveals that even inflation does not react to positive shocks in reference interest rates and the price puzzle mechanism in Serbia can be a matter of debate.

iv. The world price has be chosen as an indicator of external shocks and the study shows that 
deviznim kursom uticati na kretanje stope inflacije u Srbiji. Značaj ovog kanala je prisutan i u kretanju ukupne privredne aktivnosti. Pri tome, monetarni agregat $u$ velikoj meri utiče na kretanje ukupnog outputa. Važno je istaći i statistički neznačajan uticaj ponude novca na inflaciju, što ukazuje na nepodobnost strategije monetarnog targetiranja. I pored toga što devizni kurs ima dominantan uticaj na privredna kretanja, treba imati u vidu njegovo ograničeno dejstvo u dugom roku, te bi trebalo da monetarna vlast poradi na obezbeđivanju uslova $\mathrm{u}$ kojima bi kanal kamatne stope eventualno mogao da bude bolje iskorišćen.

\section{Literatura / References}

1. Acquah H. (2012). A bootstrap approach to evaluating the performance of Akaike Information Criterion (AIC) and Bayesian Information Criterion (BIC) in selection of an asymmetric price relationship. Journal of Agricultural Sciences, Belgrade, 57 (2), 99-110. doi: 10.2298/jas1202099d

2. Afandi A. (2005). Monetary policy transmission mechanism and structural breaks in Indonesia (PhD thesis, University of Wollongong, New South Wales). Retrieved from http://ro.uow. edu.au/theses/640

3. Al-Mashat, R., Billmeier, A. (2007). The Monetary Policy Transmission in Egypt. IMF Working Paper, 7 (285), Washington DC, USA. doi: 10. 5089/9781451868487.001

4. Aslanidi O. (2007). The Optimal Monetary Policy and the Channels of Monetary Transmission Mechanism in CIS-7 Countries: The Case of Georgia. Discussion Paper Series of Center for Economic Research and Graduate Education, 171, Charles University, Czech Republic.

5. Bernanke, B. S. Gertler, M. (1995). Inside the Black Box: The Credit Channel of Monetary Policy Transmission. Journal of Economic Perspectives, 9 (4), 27-48. doi: 10.1257/jep.9.4.27

6. Broda, C. (2006). Exchange rate regimes and the national price levels, Journal of International Economics, 70 (1), 52-81. doi: 10.1016/j.jinteco.2005.11.002

7. Bungin S. Reljić M., Ivković B. (2015). Estimation of Transmission Mechanism of Monetary Policy in Serbia. Industrija, 43 (3), 143-158. doi: 10.5937/industrija43-9076
8. Burstein A., Eichenbaum B., \& Rebelo S. (2002). Why Are Rates of Inflation So Low After Large Devaluations. NBER Working Paper, 8748. doi: 10.3386/w8748

9. Campa J., Goldberg L. (2002). Exchange Rate Pass-Through into Import Prices: A Maco or Micro Phenomenon? NBER Working Paper, 8934. doi: 10.3386/w8934

10. Charoenseang J., Manakit P. (2007). Thai Monetary policy transmission in an inflation targeting era. Journal of Asian Economics, 18 (1), 144-157. doi: 10.1016/j.asieco.2006.12.014

11. Claus I. (2011). Inside the black box: How important is the credit channel relative to interest and exchange rate channels? Economic Modelling, 28 (1-2), 1-12. doi: 10.1016/j.econmod.2010.10.006

12. Cushman D. O., Zha, T. (1997). Identifying monetary policy in a small open economy under flexible exchange rates. Journal of Monetary Economics, 39 (3), 433-448. doi: 10.1016/s0304-3932(97)00029-9

13. Dennis R. (2003). Exploring the role of the real exchange rate in Australian monetary policy. Economic Record, 79 (244), 20-38. doi: 10.1111/1475-4932.00076

14. Devereux M., Engel, C., Storgaard, P. (2003). Endogenous Exchange rate pass-through when nominal prices set in advance. NBER Working Paper, 9543. doi: 10.3386/w9543

15. Dragutinović D. (2008). Moć i nemoć monetarne politike u uspostavljanju ravnoteže između platnobilansnih ciljeva i ciljeva inflacije. Working Paper Series 12, National Bank of Serbia. 
it does not have a more significant effect than domestic shocks, but it must be noted that it participates in the fluctuations of the total output with almost $12 \%$.

The macroeconomic implications of these results primarily refer to the fact that the monetary authorities can influence the movement of inflation rate in Serbia by controlling the exchange rates. This channel is also important for the total economic activity. Monetary aggregate has a strong influence on the total output movements. It is important to note that there is a statistically non-significant impact of money supply on inflation, which indicates that the strategy of monetary targeting is inadequate. Even though the exchange rate has a dominant role on the economic trend, we must bear in mind that in the long run its effects are limited, hence the monetary authorities should be obliged to ensure the conditions in which the interest rate channel could be better utilized.
16. Gerlach S., Smets, F. (1995). The Monetary Transmission Mechanism: Evidence from the G-7 Countries. BIS Working Paper, 26. doi: $10.2139 /$ ssrn. 868427

17. Goeltom, S. M. (2008). The Transmission Mechanism of Monetary Policy in Indonesia. BIS Working Paper, 351.

18. Horvath B., Maino, R. (2006). Monetary Transmission Mechanisms in Belarus. IMF Working Paper, 246.

19. Kara H., Ogunc, F. (2005). Exchange Rate Pass Through in Turkey: It is Slow, but is it Really Low? Research Department Working Papers, 05/10, The Central Bank of the Republic of Turkey.

20. Kim S., Roubini, N. (2000). Exchange rate anomalies in the industrial countries: A solution with a structural VAR approach, Journal of Monetary Economics, 45 (3), 561-586. doi: 10.1016/s0304-3932(00) 00010-6

21. McCallum B. T., Nelson, E. (2001). Monetary Policy for an Open Economy: An Alternative Framework with Optimizing Agents and Sticky Prices. NBER Working Paper, 8175. doi: 10.3386/w8175

22. McCarthy J. (2007). Pass-Through of Exchange Rates and Import Prices to Domestic Inflation in Some Industrialized Economies. Eastern Economic Journal, 33 (4), 511-537. doi: 10.1057/eej.2007.38

23. Mishkin F. S. (2001). The Economics of Money, Banking, and Financial Markets. $6^{\text {th }}$ Edition, Addison Wesley Publishing Company

24. NBS. (2017). Retrieved from http://www. nbs.rs/internet/cirilica/80/index.html
25. Ndungu, N. S. (1999). Monetary and Exchange rate policy in Kenya. AERC Research Paper, 94.

26. Obstfeld, M., Rogoff, K. (1995). Exchange Rate Dynamics Redux. Journal of Political Economy, 103 (3), 624-660. doi: 10.1086/261997

27. Poon, C-c., Wong, F-k. (2011), China's Monetary Policy and Its Transmission Mechanisms Before and After the Financial Tsunami. Chinese Economy, 44 (3), 84-108. doi: 10.2753/ces1097-1475440306

28. Raghavan, M., Silvapulle, P. (2010). Malaysian monetary transmission mechanism: Evidence from the preand post-Asian financial crisis periods. International Conference on Management Science \& Engineering $17^{\text {th }}$ Annual Conference Proceedings. doi: 10.1109/icmse.2010.5719930

29. Republički zavod za statistiku. (2017). Retrieved from http://webrzs.stat.gov.rs/ WebSite/

30. Taylor, J., B. (1995). The Monetary Transmission Mechanism: An Empirical Framework. Journal of Economic Perspective, 9 (4), 11-26. doi: 10.1257/jep.9.4.11

31. U.S. Energy Information Administration (2017). Retrieved from http://www.eia.doe. gov/dnav/pet/TblDefs/pet_pri_spt_tbldef2. asp

32. Vilaret S., Palić, M, (2006), Pass-through efekat deviznog kursa na inflaciju u Srbiji. Working Paper Series, 5, National Bank of Serbia 